\title{
Preserving Javanese Language by Translating Traditional Song used in Dieng's Dreadlock Hair Cutting Tradition to Support Banjarnegara Local Tourism
}

\author{
${ }^{1}$ Ersa Alysia, Wiwiek Sundari, Hadiyanto, Atrinawati \\ ${ }^{1}$ English Literature Study Program, Faculty of Humanities, Diponegoro University, Semarang, \\ Indonesia.
}

\begin{abstract}
Language is served as evidence of human being civilization. Through language, culture is shared. When a language goes extinct after its speakers are gone, a culture is also threatened. To preserve a language and the culture embedded in it, language maintenance is needed. One of the ways to do it is by translating the language for foreign visitors in a tourism event. This research shows how the Javanese language is translated in a song containing prayer in a religious-traditional tourism event called Ngruwat, in Dieng, Banjarnegara, Central Java. The data were collected and analyzed using translation theory and methodology. The result shows that translating the old Javanese language means learning the language and exposing it to people who serve as language and culture maintenance.
\end{abstract}

\section{Research Background}

Local Local language preservation or maintenance is an interesting topic to be discussed by countries possessing endangered local or indigenous languages due to the extinction of its speakers or their descendants' language shift who are choosing more beneficial languages than their ancestors' language or deciding to select one of their parents' dominant languages in a mix-marriage family. Moreover, a negative attitude toward the language due to political, economic and social changes decreases the value, usage and respect [1].

Dharma [2] in Savitri [3] suggests two primary efforts to preserve the endangered language. They are language development and language building. The first one can be done through language research, inventory, and documentation. Therefore, the observation, the listing and the recording (the saving) of endangered languages lead to authentic evidence of those languages. The second one can be done by scaffolding the endangered language use in family, school, and society. It means that those three language communities must be supported by the whole language environment, including the local government. The language teaching at school, the language use at home and the social support of the language used by providing public media to communicate using the language lets the young generation know (recognize), understand and use the language. 
As language preservation can be done by supporting the endangered language use in the society, it can be done by using it in a community like in a tourism event. One of the examples of that medium is a tourism event. In a local religious, traditional, and cultural tourism event, the local language is used as part of the event like the language used in the ritual, the name of the ritual's apparatus, the name of the food offerings, and the description made for the tourist who comes to see the event. This research shows how the Javanese language -as one of the local Indonesian languages that can be endangered if it is not preserved- is maintained in a translation of religious, traditional, and cultural tourism event called Ngruwat, held by Dieng society and supported by Banjarnegara local government to cut natural dreadlock hair of particular kids in Dieng.

\section{Theoretical Background}

Translation Translation means transferring the author's intended message from his/her text in his/her language into another language by highly considering how the familiar or particular readers will understand and enjoy the translation while getting the message and obtaining the needed information from the text. Translating folklore-based text in religious, traditional, and cultural tourism events can be challenging for a translator as he/she needs to transfer the message without losing the cultural taste of the text or ignoring the reader's need for accurate information. Sometimes translator keeps the original language, added with a footnote, to fully explain the word. In this way, the translator preserves the original language through his translation.

This research shows how the translator keeps the Javanese language as a local language in a religious, traditional, and cultural tourism event called Ngruwat, in Dieng, Banjarnegara, Central Java. The old Javanese language text in a song containing prayer is obtained using Dundes's folklore research [4] in two methods, Identification and Interpretation. Meanwhile, the translation is done using Venuti's translation model [5] and Vinay and Darbelnet's translation methods and techniques [6]. The translation is beneficial for preserving and introducing the old version of the language by adding traditional flavour to the translation and promoting the tourism event as foreign tourists will be interested in the local language, the folklore behind the event and the tourism event itself.

\section{Research Methodology}

This research is done in virtual ways to obey Covid-19 health protocol. Library research is done by taking the song as the research object from the local government document and Nugroho's research [7] on the tourism event. The data is chosen using the Purposive Sampling Technique [8] to select the song containing prayer in old Javanese language that is no longer spoken in todays' daily communication of Javanese people. The researcher also took 1 (one)research subject who was hosting the tourism event using the Purposive Sampling Technique [8] who understood the song to get more information to support the translation process.

The researcher digs more information from an informant who joins the tourism event by giving a virtual Questionnaire and holding a virtual Interview [9] to see how foreign visitors understand the translated song and whether he is interested in learning the original language. The data were then analysed using Dundes's folklore research [4], Venuti's translation model [5], and Vinay and Darbelnet translation methods and techniques [6] to figure out (1) how the song was translated, (2) how Dieng people maintain the Javanese language, and (3) the reason why they maintain it. 


\section{Finding and Discussion}

\subsection{Finding}

The researcher found a religious-traditional song written in an old Javanese language that is no longer used nowadays in Javanese people's daily communication. The song contains a mantra used by an old and respected Javanese religious leader whose duty is to ensure the future life-safety of Dieng kids whose natural he will cut dreadlock hair. This song also contains a prayer sung by a particular traditional singer appointed by the religious leader to perform the special duty since commoners cannot perform it. The song was also performed during the ceremony for the sake of the kids' safety. The song will be translated and discussed in the next sub-chapter.

\subsubsection{Dieng, Banjarnegara and Wonosobo, Central Java}

Dieng is split into two different administrative areas, the West Dieng in Banjarnegara District and the East Dieng in Wonosobo District, Central Java. As it is located at 6.802 feet height or 2.093mdpl above the sea level with a geographical position of 7'12' North Latitude and 109'54' East Longitude, this plateau is known for its cold temperature of $15 \mathrm{oC}$ on regular days and reaching $0 \mathrm{oC}$ on cold days, which is uncommon for Central Java average temperature.

The cold temperature, the beautiful scenery, the hail, and the frosty plants go viral that attract visitors besides being interested in Dieng famous archaeological sites such as temples and craters. Another well-known Dieng tourism attraction is the annual Ngruwat tourism event, or the cutting of Dieng kids' natural dreadlock hair that must be cut in a special ceremony served as a religious, traditional and cultural tourism attraction [7].

\subsubsection{Kids with Natural Dreadlock Hair}

From The virtual folklore research found out that there are special kids in Dieng who grow natural dreadlock hair called gimbal or gembel. Dieng people believe that they are Kyai Kolodete descendants, the ancestor of Dieng, who lived during the era of the Mataram Kingdom. Kyai Kolodete was the person who came and opened the plateau and then made it into a place to live. Now, it has already been developed into an administrative area in Central Java. Since Kyai Kolodete has natural dreadlock hair, Dieng people believe that the kids with natural dreadlock hair were his descendants [10].

Dieng people believe that those kids are special as not all Dieng kids has that kind of hair. These special kids, aging below 5 (five) years old, were naturally growing the hair after a high fever and a delirious. No medication can cure the kids since they will be recovered by themselves. The recovered kids get tangled hair as a result of the heavy sweat during the high fever. The tangled hair cannot be unravelled even though it has been washed with any soap or shampoo. When the hair is cut, the new hair will naturally grow like dreadlock hair which is denser and tangler.

To altogether remove the hair, the kids' parents and Dieng local people must hold a religious, traditional, and cultural ceremony called ngruwat in which the hair will be cut by an old and respected Javanese religious leader under a particular requirement that must be done to keep the kids safe, and the ceremony runs well. In the ceremony, the kids have the privilege to ask for any gifts they want from their parents as a reward for their willingness to cut (or remove) the dreadlock hair. Alternatively, the dreadlock hair will grow back after the ceremony, just like being casually cut by a commoner. 


\subsubsection{Ngruwat Ceremony}

Ngruwat is a religious, traditional, and cultural ceremony held in Arjuna Temple areas by Dieng local people, supported by Banjarnegara local government as an annual tourism event called Dieng Culture Festival. This ceremony is specially held to cut Dieng kids' natural dreadlock hair, to prevent them from having bad luck from the hair, to ask for God's mercy and blessing for the kids and the whole Dieng people and to attract local, regional, and international tourists to enjoy this tourism event.

In the ceremony, there is a song entitled Kidung Rumeksa ing Wengi, sung by a particular singer appointed by an old and respected Javanese religious leader who use mantra to keep the kids safe and then cut the kids hair. This religious-traditional song is written in an old Javanese language with Krama Inggil politeness level that is no longer spoken by Javanese people in their daily communication nowadays. The researcher translated the song and then sent it back to Dieng, Banjarnegara, local government to be shared with the foreign visitor who attends the ceremony. The researcher asks the host about the correct translation and the visitor about their opinion about the translation.

Tabel 1. The Correct Translation and the Visitor About Their Opinion About the Translation.

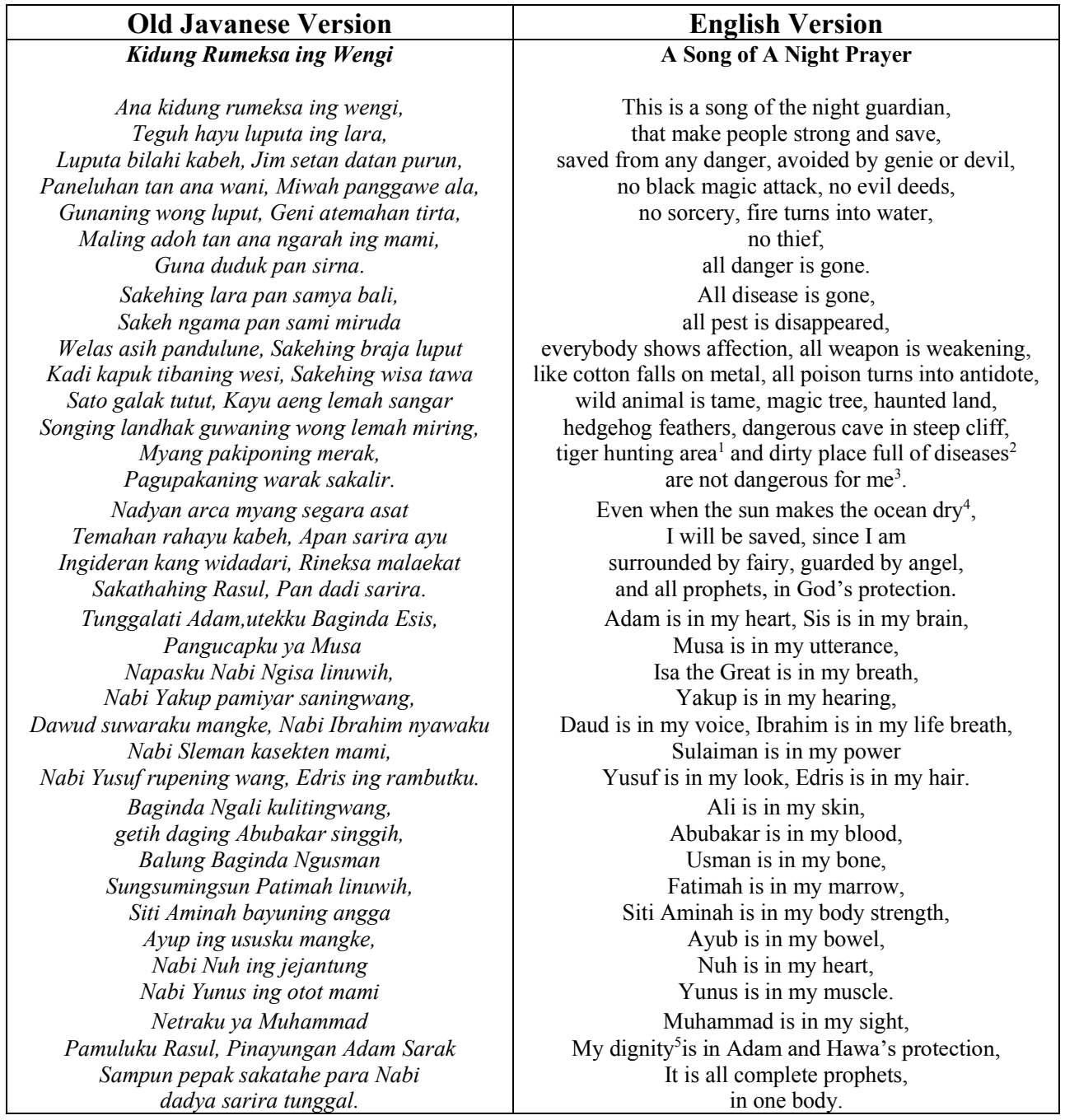


The The song is translated using Venuti's translation model [5] by keeping the original name to avoid misunderstanding due to different cultural backgrounds. It is also translated by applying Vinay and Darbelnet [6] two translation methods (direct and oblique translation) and seven translation techniques (borrowing, calque, literal, transposition, modulation, equivalence or reformulation and adaptation) to deliver the message to the visitors.

Two phrases (peacock nest and rhino puddle) and two words (arca and face) were non literally translated into tiger hunting area1, a dirty place full of disease2, the sun3, and dignity 5 to let people understand the meaning lies behind its metaphors. Meanwhile, the phrase 'is not dangerous for me3' is added to explain why the real dangers were mentioned.

According to the ceremony host, this song is Sunan Kalijaga inheritance (Islamic holy figure who was spreading Islam in Java) which serves as a lullaby full of good prayer from parents to their children to be saved from any danger, to get the strength of the prophets, and to be blessed by the God. This song is called Mantrawedha, which is inspired by the Holy Quran's verses. It consists of 10 (ten) pupuh (Javanese poet), which is sung in the Dhandanggula version (traditional Javanese song, called macapat, consisting of eleven songs, including Dhandanggula).

It is hoped that God will accept the spelt mantra and the spoken prayer by singing the song. Thus, the kids with dreadlock hair will be saved for the rest of their life. It is said that anybody who wants to sing the song should do mutih fasting (eating food with white colour) for forty days and ngebleng fasting (not eating nor drinking) for a night before singing the song eleven times to get the blessing.

By understanding what is being sung in an old Javanese language song, a foreign visitor has been exposed to Javanese people way of thinking and living as well as the old Javanese language as it is written in bilingual text. In this way, the tourism event can draw tourists' interest in knowing more about the story, the language and the culture behind the whole ceremony. Therefore, the translation indirectly introduces the Javanese language and the culture that will be kept by Javanese people and might be learnt by others such as foreigners.

The way translation is used in tourism as one of the ways to introduce the folklore along with the local language that serves as local language maintenance can be seen in the use of English on the famous historical trip of The Killing Fields in Choeung Ek Village, approximately $15 \mathrm{~km}$ southeast of Phnom Penh, the capital city of Cambodia [11]. Visitors were offered to visit 19 massive burial sites by walking, equipped with a recording in English (and some local people testimonials using local language along with its translation in English) to listen to while visiting the 19th locations and able to read the explanation (translated in English along with the local language font and its translation) on the information boards about what happens in a specific site they visit on all along the way to the 19 locations.

\section{Conclusion}

From the finding and discussion in the previous chapter, their searcher found out that Dieng people and Banjarnegara local government had already preserved the Javanese language through the religious, traditional, and cultural tourism event called Ngruwat. The translation of the song sung during this ceremony is part of the language maintenance effort as it will expose the language to the visitors who might get interested in knowing the story, learning the language and understanding the culture. This effort becomes another way of preserving the Javanese language besides using it in traditional ceremonies [12] as it is done by translating the language into English so that language can be maintained by the local Javanese people who translate it into English and can be introduced to foreigners who were stimulated by the translation to learn the language. 


\section{References}

[1] Holmes, J. An Introduction to Sociolinguistics. New York: Longman (1992)

[2] A. Dharma. "Pembinaan dan Pengembangan Bahasa Daerah." in proceeding of International Seminar on Language Maintenance and Shift. Linguistics Master Program Diponegoro University, July 7th, 2011; Semarang, Indonesia.

[3] Savitri, A.I. and Atrinawati. "Penerjemahan Folklore untuk Pengembangan Pariwisata di Pekalongan”. Penelitian Hibah Fakultas Ilmu Budaya. Universitas Diponegoro. (2018)

[4] Bronner, S.J. (ed.). The Meaning of Folklore: The Analytical Essays of Alan Dundes. Logan, Utah: Utah State University Press. (2007)

[5] Venuti. L. The Translation Studies Reader. London: Routledge. (2000)

[6] Vinay, J.P. and Darbelnet, J. A Methodology for Translation. [An excerpt from Comparative Stylistics of French and English: A Methodology for Translation, trans. and eds. J. C. Sager \& M.J. Hamel, Amsterdam: John Benjamins, 1995, first published in 1958 as Stylistique comparée du français et de l'anglais. Méthode de traduction] In L. Venuti (Ed.), The Translation Studies Reader (pp. 84-93). London: Routledge. $(1958 / 2000)$

[7] Nugroho, S.A. Upacara Ngruwat Gimbal di Desa Dieng Kulon Kecamatan Batur Kabupaten Banjarnegara. Final Paper. Yogyakarta. UNY. (2014)

[8] Sugiyono. Metode Penelitian Kualitatif dan R\&D. Bandung: CV Alfabeta (2010)

[9] Sudaryanto. Metode dan Aneka Teknik Analisis Bahasa. (Pengantar Penelitian Wacana Kebudayaan secara Linguistik). Yogyakarta: Duta Wacana (1993)

[10] Febrianda, Y. Mitos Anak Gembel Pada Masyarakat Dataran Tinggi Dieng. http://catatansikudaliar.blogspot.com/2015/10/mitos-anak-gembel-padamasyarakat.html. (2015)

[11] Savitri, A.I. Local Language Maintenance through Folklore Translation in Historical Tourism. Article on International Conference CL-LAMAS Proceeding. Semarang: August, $13^{\text {th }}-14^{\text {th }},(2019)$.

[12] Sundari, W. Javanese Culture Maintenance at Dhoplang Traditional Culinary Market,

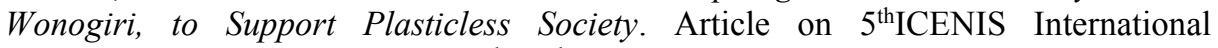
Proceeding. Semarang: August, $12^{\text {th }}-13^{\text {th }},(2020)$. 